\title{
Isomeric Ion-Neutral Complexes Generated from Ionized 2-Methylpropanol and $n$-Butanol: the Effect of the Polarity of the Neutral Partner on Complex-Mediated Reactions
}

\author{
John C. Traeger \\ Department of Chemistry, LaTrobe University, Bundoora, Victoria, Australia
}

\section{Charles E. Hudson and David J. McAdoo}

Marine Biomedical Institute and Department of Human Biological Chemistry and Genetics, University of Texas Medical Branch, Galveston, Texas, USA

\begin{abstract}
Photoionization was used to characterize the energy dependence of $\mathrm{C}_{3} \mathrm{H}_{7}^{+}, \mathrm{C}_{3} \mathrm{H}_{6}^{+}$, $\mathrm{CH}_{3} \mathrm{OH}_{2}^{+}$, and $\mathrm{CH}_{2}=\mathrm{OH}^{+}$formation from $\left(\mathrm{CH}_{3}\right)_{2} \mathrm{CHCH}_{2} \mathrm{OH}^{+\cdot}{ }^{\prime}$ (1) and $\mathrm{CH}_{3} \mathrm{CH}_{2} \mathrm{CH}_{2} \mathrm{CH}_{2} \mathrm{OH}^{+}$(2). Decomposition patterns of labeled ions demonstrate that close to threshold these products are primarily formed through $\left[\mathrm{CH}_{3}^{+} \mathrm{CHCH}_{3} \mathrm{CH}_{2} \mathrm{OH}\right](3)$ from 1 and through $\left[\mathrm{CH}_{3} \mathrm{CH}_{2} \mathrm{CH}_{2}{ }^{\cdot} \mathrm{CH}_{2}=\mathrm{OH}^{+}\right]$(9) from 2. The onset energies for forming the above products from 1 are spread over $85 \mathrm{~kJ} \mathrm{~mol}^{-1}$, and are all near thermochemical threshold. The corresponding onsets from 2 are in a $19 \mathrm{~kJ} \mathrm{~mol}^{-1}$ range, and all except that of $\mathrm{CH}_{2}=\mathrm{OH}^{+}$are well above their thermochemical thresholds. Each decomposition of 3 occurs over a broad energy range ( $\left.>214 \mathrm{~kJ} \mathrm{~mol}^{-1}\right)$. This demonstrates that inn-permanent dipole complexes can be significant intermediates over a much wider energy range than ion-induced dipole complexes can be. Hexchange between partners in the complexes appears to be much faster than exchange by conventional interconversions of the alcoho] molecular ions with their distonic isomers. The onsets for water elimination from 1 and 2 are below the onsets for the complex-mediated processes, demonstrating that the latter are not necessarily the lowest energy decompositions of a given ion when the neutral partner in the complex is polar. (J Am Soc Mass Spectrom 1992, 3, 409-416)
\end{abstract}

$\mathrm{M}$ any unimolecular decompositions of ions in the gas phase take place by reactions between electrostatically bound partners created by dissociation of a bond in the initially formed ion [1]. The following expression from the average dipole orientation theory of ion-molecule reactions [2] indicates the components of the interaction potential at the distances that exist between the partners in ion-neutral complexes.

$$
\mathrm{U}=-\mu_{D} q \cos \theta / r^{2}-\alpha q^{2} / 2 r^{4}+L^{2} / q \mu r^{2}
$$

In this expression $\mu_{D}$ is the dipole moment of the neutral, $q$ is the charge on the ion, $\theta$ is the average angle between the dipole moment and the line of collision, $\mathrm{r}$ is the distance between the particles, $\alpha$ is the polarizability of the neutral, $L$ is the orbital angu-

Address reprint requests to David J. McAdoo, Marine Biomedical Institute, University of Texas Medical Branch, 200 University Boulevard, Galveston, TX 77550 . lar momentum of the two particles, and $\mu$ is the reduced mass of the two particles. When present, a large dipole moment is the major contributor to the attraction between the partners. Therefore, a large dipole moment in the neutral may considerably expand the energy range over which an ion-neutral complex is a significant intermediate $[3,4]$, a possibility we further explore here.

Complex-mediated reactions include the formation of protonated species from ionized 2-methylpropanol (1), neopentyl alcohol, neopentyl ethers, and neopentyl amines [5]. Such products are much less abundant in the spectra of the isomeric straight chain isomers. Differences in decomposition patterns could stem from formation of the ion-dipole complex $\left[\mathrm{CH}_{3}^{+} \mathrm{CHCH}_{3}\right.$ $\cdot \mathrm{CH}_{2} \mathrm{OH}$ (3) from 1 and the ion-induced dipole complex $\left[\mathrm{CH}_{3} \mathrm{CH}_{2} \mathrm{CH}_{2} \cdot \mathrm{CH}_{2}=\mathrm{OH}^{+}\right]$(9) from 2. Formation of these isomeric complexes would permit comparison of the energy dependencies of complexmediated reactions involving polar and nonpolar neutral partners. To broaden our knowledge of these 
energy dependencies, we examined the formation of $\mathrm{CH}_{3} \mathrm{OH}_{2}^{+}$and the mechanistically related products $\mathrm{C}_{3} \mathrm{H}_{7}^{+}, \mathrm{C}_{3} \mathrm{H}_{6}^{+}$and $\mathrm{CH}_{2}=\mathrm{OH}^{+}$from 1 and 2 .

\section{Results and Discussion}

Fragmentations of ionized 2-methylpropanol. A potential energy diagram representing the reactions of 1 that will be considered is given in Figure 1. A partial mass spectrum of 2-methylpropanol at $12.60 \mathrm{eV}$ photon energy is given in Table 1 . At this energy, the dominant fragments are $\mathrm{C}_{3} \mathrm{H}_{7}^{+}, \mathrm{C}_{3} \mathrm{H}_{6}^{+}$and $\mathrm{CH}_{3} \mathrm{OH}_{2}^{+}$.

The $\mathrm{H}$-transfers that form methanol suggest that the main pathway from 1 to $\mathrm{CH}_{3} \mathrm{OH}_{2}^{+}$is $1,3,4$ $\rightarrow 5$ (Scheme I). At $-2 \times 10^{-11} \mathrm{~s} \mathrm{CH}_{2} \mathrm{DOH}$ is specifically eliminated from $1-3,3,3,3^{\prime}, 3^{\prime}, 3^{\prime}-\mathrm{d}_{6}[6]$. This requires methanol formation by $\mathrm{H}$-transfer to $\mathrm{C} 1$ in 3 or $\left[\mathrm{CH}_{3} \mathrm{CHCH}_{3} \mathrm{CH}_{2}=\mathrm{OH}^{+}\right]$, as going by way of $\mathrm{CD}_{2} \mathrm{CH}\left(\mathrm{CD}_{3}\right) \mathrm{CH}_{2} \mathrm{OHD}^{+} \rightarrow\left[{ }^{\circ} \mathrm{CH}_{2} \mathrm{OHD}^{+} \mathrm{CD}_{2}\right.$ $=\mathrm{CHCD}_{3}$. (Scheme II) would produce as much $\mathrm{CH}_{2} \mathrm{DOD}$ as $\mathrm{CH}_{2} \mathrm{DOH}$ (assuming small isotope effects). $\left[\mathrm{CH}_{3} \mathrm{CHCH}_{3} \mathrm{CH}_{2}=\mathrm{OH}^{+}\right]$would be less stable than 3 because, in addition to the $23 \mathrm{~kJ} \mathrm{~mol}{ }^{1}$ lesser stability of the separated partners, ion-dipole
Table 1. Partial mass spectra of 2-methylpropanol and $n$-butanol

\begin{tabular}{ccc}
\hline$m / z$ & 2-Methylpropanol & $n$-Butanol \\
\hline \hline 31 & 0.07 & 0.14 \\
33 & 1.00 & 0.05 \\
42 & 1.00 & 0.18 \\
43 & 0.96 & 0.19 \\
56 & 0.09 & 1.00 \\
74 & 0.36 & 0.03 \\
\hline
\end{tabular}

Spectra were obtained on a photoionization mass spectrometer at a photon energy of $12.60 \mathrm{eV}$.

attractions (eq 1) enhance the stability of 3 relative to that of $\left[\mathrm{CH}_{3} \mathrm{CHCH}_{3} \mathrm{CH}_{2}=\mathrm{OH}^{+}\right]$. Thus only 3 would be formed near threshold.

An alternate pathway that would accuunt for the exchange is presented in Scheme $\Pi I$. This process can be ruled out however, as reactions such as the first step seem not to occur [7], and ionized $i$-propyl methyl ether does not interconvert with its ylid isomer. Protonated methanol is therefore probably formed by $4 \rightarrow 5$, as $1 \rightarrow 3 \rightarrow 4$ seems demonstrated.

The pathway to water elimination from $1[8]$ and a

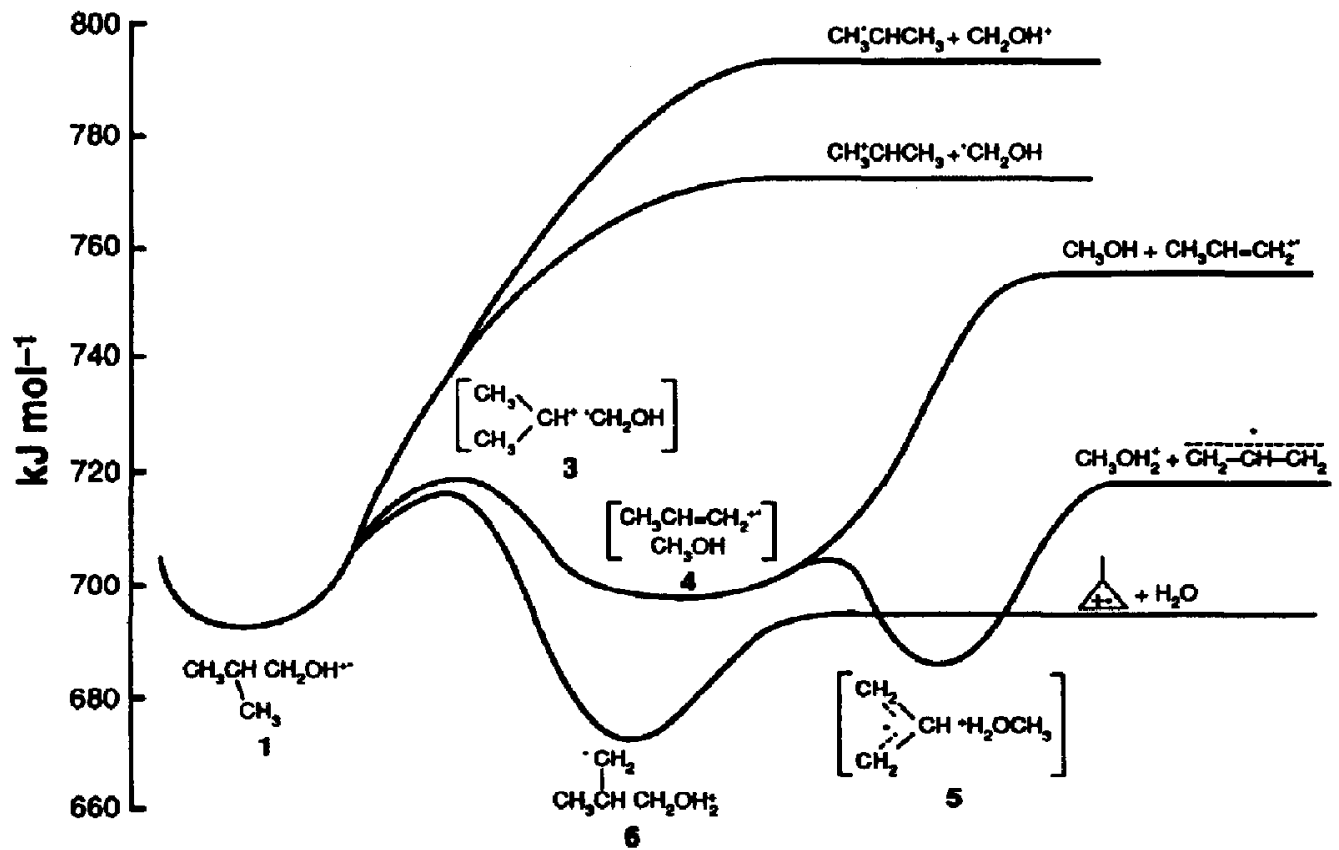

Figure 1, Potential energy diagram for the reactions of ionized 2-methylpropanol (1). The dissociated species and 1 are placed according to the heats of formation in Table 1 , except $\mathrm{CH}_{3} \mathrm{OH}_{2}^{+}+\mathrm{CH}_{2} \cdot \mathrm{CHCH}_{2}$ is placed according to its appearance energy. [ $\mathrm{CH}_{3}^{+} \mathrm{CHCH}_{3} \cdot \mathrm{CH}_{2} \mathrm{OH}$ ] is at $\mathrm{AE}\left(\mathrm{CH}_{3} \mathrm{OH}_{2}^{+}\right)$. The transition state for $1 \rightarrow 6$ is at $\mathrm{AE}\left(\mathrm{C}_{4} \mathrm{H}_{8}^{+}\right)$. Because $\Delta \mathrm{H}_{f}\left(\mathrm{CH}_{2} \mathrm{CH}_{2} \mathrm{CH}_{2} \mathrm{OH}_{2}^{+}\right)$ is $17 \mathrm{~kJ} \mathrm{~mol}^{-1}$ below $\Delta \mathrm{H}_{\mathrm{f}}\left(\mathrm{CH}_{3} \mathrm{CH}_{2} \mathrm{CH}_{2} \mathrm{OH}^{+,}\right)$[22], 6 is placed $17 \mathrm{~kJ} \mathrm{~mol}^{-1}$ below 1 . An attraction of $59 \mathrm{~kJ} \mathrm{~mol}^{-1}$ between polar neutrals and ions was assumed based on $\mathrm{AE}\left(\mathrm{C}_{3} \mathrm{H}_{7}^{+}\right)-\mathrm{AE}\left(\mathrm{CH}_{3} \mathrm{OH}_{2}^{+}\right)$. On this basis $\Delta \mathrm{H}_{f}(4)$ was placed $59 \mathrm{~kJ} \mathrm{~mol}^{-1}$ below the combined heats of formation of its separated partners. An attraction of $30 \mathrm{~kJ} \mathrm{~mol}^{-1}$ was assumed between ions and nonpolar neutrals based on a difference of at least $28 \mathrm{~kJ} \mathrm{~mol}^{-1}$ between the thresholds for propyl and propane losses from ionized 2-methoxypentane [15d]. 


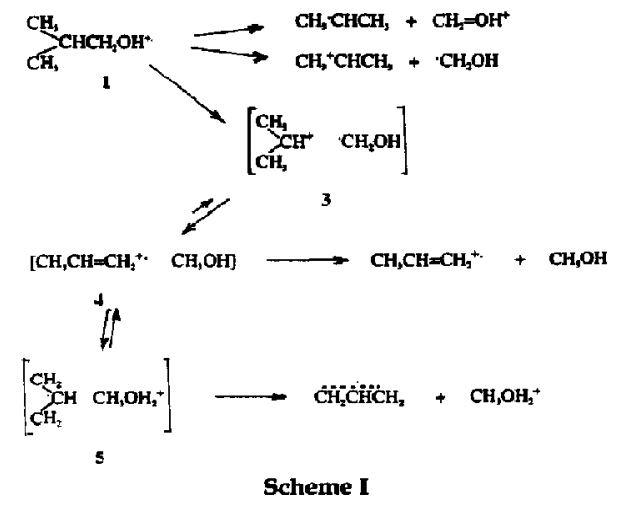

related potential pathway to $\mathrm{CH}_{3} \mathrm{OH}_{2}^{+}$is given in Scheme II.

The initial $\mathrm{H}$-transfer in Scheme 11 must precede $\mathrm{H}_{2} \mathrm{O}$ elimination, the dominant metastable decomposition of $\mathbf{1}$ [9] (see below). However, there is no exchange between the hydroxyl and methyl hydrogens of 1 before metastable elimination of water [6]. so exchange by $1 \rightleftarrows 6$ is not significant. This contrasts with substantial exchange of the hydroxyl and methyl hydrogens of 1 prior to formation of both $\mathrm{CH}_{3} \mathrm{CH}=\mathrm{CH}_{2}^{+\cdot}$ and $\mathrm{CH}_{3} \mathrm{OH}_{2}^{+}[5 a, 6]$. The differences in $\mathrm{H}$-exchange require initiation of water elimination and $\mathrm{CH}_{3} \mathrm{OH}_{2}^{+}$formation from 1 by distinct processes, i.e., $\mathrm{CH}_{3} \mathrm{OH}_{2}^{+}$is produced according to Scheme $\mathrm{I}$ and water is eliminated according to Scheme II. $\mathrm{CH}_{3} \mathrm{OH}_{2}^{+}$ is probably not formed by $6 \rightarrow 7 \rightarrow 5$ because of competition from the lower energy pathway $1 \rightarrow 3 \rightarrow 4 \rightarrow$ 5. $\left(\Delta \mathrm{H}_{\mathrm{f}}\left(\mathrm{CH}_{3} \mathrm{CH}=\mathrm{CH}_{2}\right)+\Delta \mathrm{H}_{\mathrm{f}}\left(\mathrm{CH}_{2} \mathrm{OH}_{2}^{+}\right)\right.$is $62 \mathrm{~kJ}$ $\mathrm{mol}^{-1}$ above $\Delta \mathrm{H}_{\mathrm{f}}\left(\mathrm{i}-\mathrm{C}_{3} \mathrm{H}_{7}^{+}\right)+\Delta \mathrm{H}_{\mathrm{f}}\left(\mathrm{CH}_{2} \mathrm{OH}\right)$ and 78 kJ $\mathrm{mol}^{-1}$ above $\Delta \mathrm{H}_{\mathrm{f}}\left(\mathrm{CH}_{3} \mathrm{CH}=\mathrm{CH}_{2}^{+-}\right)+$ $\Delta \mathrm{H}_{\mathrm{f}}\left(\mathrm{CH}_{3} \mathrm{OH}\right)$; heats of formation of the individual species are given in Table 2.) The difference in exchange patterns answers the challenging question [10]: Does exchange in this system occur by interconver-

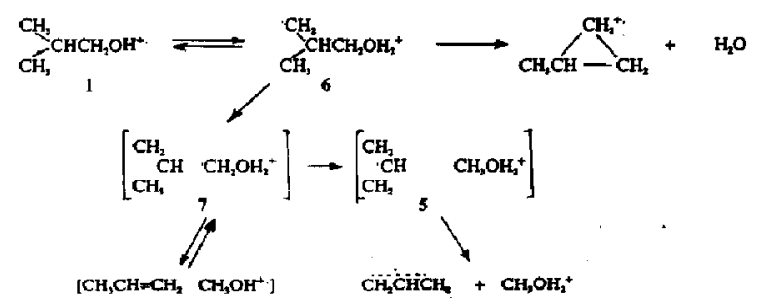

Scheme II

sion of complexes (Scheme I) or by reversible isomerization (Scheme II)? It occurs by interconversion of complexes.

By $-4 \times 10^{-10} \mathrm{~s}$, near randomization of methyl and hydroxyl hydrogens accompanies $\mathrm{CH}_{3} \mathrm{OH}_{2}^{+}$formation [6]. This is considerably faster than $\mathrm{H}$-exchange by interconversion of distonic ions, which can take $10^{-8}-10^{-7} \mathrm{~s}$ to become appreciable [11]. This suggests that complex-mediated $\mathrm{H}$-exchange can be orders of magnitude faster than conventional $\mathrm{H}$-transfers in ions.

Exchange of the $\mathrm{C} 1$ hydrogens is much slower than exchange of the hydroxyl and methyl hydrogens in 1 $[5 a, 6]$. This presumably reflects a higher rate of $4 \rightleftarrows 5$ than of $4 \rightleftarrows 3$. Such a higher rate is plausible, because 5 is more stable than 3 (Figure 1). The dominant exchange could also reflect a preferred orientation of the negative end of the dipole of methanol toward the charged partner in 4 , as such a preferred orientation is reflected in low energy ion-molecule reactions of methanol [12]. The alternative exchange mechanism, $4 \rightleftarrows\left[\mathrm{CH}_{3}^{+} \mathrm{CHCH}_{3} \quad \mathrm{OCH}_{3}\right]$ is less likely because the last complex would be about $41 \mathrm{~kJ} \mathrm{~mol}^{-1}$ $\left(\Delta \mathrm{H}_{\mathrm{f}}\left[\mathrm{CH}_{3} \mathrm{O}^{\cdot}\right]-\Delta \mathrm{H}_{\mathrm{f}}\left[\mathrm{CH}_{2} \mathrm{OH}\right]\right)$ higher in energy than 3.

Energy dependence of the complex-mediated fragmentations of 1 . We obtained the onsets and energy dependen-

Table 2. Pertinent heats of formation

\begin{tabular}{|c|c|c|c|}
\hline$\left(\mathrm{CH}_{3}\right)_{2} \mathrm{CHCH}_{2} \mathrm{OH}$ & -283.6 & $\left(\mathrm{CH}_{3}\right)_{2} \mathrm{CHCH}_{2} \mathrm{OH}^{+-}$ & 692 \\
\hline $\mathrm{CH}_{3} \mathrm{CH}_{2} \mathrm{CH}_{2} \mathrm{CH}_{2} \mathrm{OH}$ & -275 & $\mathrm{CH}_{3} \mathrm{CH}_{2} \mathrm{CH}_{2} \mathrm{CH}_{2} \mathrm{OH}^{+}$. & 696 \\
\hline $\mathrm{CH}_{3} \cdot \mathrm{CHCH}_{3}$ & 93.3 & $\mathrm{CH}_{3}^{+} \mathrm{CHCH}_{3}$ & 798.9 \\
\hline $\mathrm{CH}_{3} \mathrm{CH}_{2} \mathrm{CH}_{2}^{-}$ & 100.5 & $\mathrm{CH}_{3} \mathrm{CH}_{2} \mathrm{CH}_{2}^{+}$ & 881 \\
\hline $\mathrm{CH}_{3} \mathrm{CH}=\mathrm{CH}_{2}$ & 20.2 & $\mathrm{CH}_{3} \mathrm{CH}=\mathrm{CH}_{2}{ }^{+\cdot}$ & 959 \\
\hline $\mathrm{CH}_{2} \mathrm{CH}_{2} \mathrm{CH}_{2}$ & 53.3 & 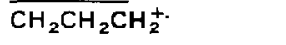 & 1004 \\
\hline $\mathrm{CH}_{2} \mathrm{C} \mathrm{HCH} \mathrm{H}_{2}$ & $165.2^{a}$ & $\mathrm{CH}_{3} \mathrm{CH}_{2} \mathrm{CH}=\mathrm{CH}_{2}^{+} \cdot$ & 924 \\
\hline$\overline{\mathrm{CH}_{2} \mathrm{CH}_{2} \mathrm{CH}_{2} \mathrm{CH}_{2}^{+}}$. & 985 & $\mathrm{CH}_{3} \mathrm{C}\left(\mathrm{CH}_{3}\right)=\mathrm{CH}_{2}^{+}$. & 874 \\
\hline $\mathrm{CH}_{3} \overline{\mathrm{CHCH}_{2} \mathrm{CH}_{2}^{+}}$ & 938 & $\mathrm{H}_{2} \mathrm{O}$ & -241.8 \\
\hline $\mathrm{CH}_{2} \mathrm{OH}$ & -25.9 & $\mathrm{CH}_{2}=\mathrm{OH}^{+}$ & 703 \\
\hline $\mathrm{CH}_{3} \mathrm{OH}$ & -201.6 & $\mathrm{CH}_{3} \mathrm{OH}^{+}$ & 845.3 \\
\hline$\cdot \mathrm{CH}_{2} \mathrm{OH}_{2}^{+}$ & 815 & $\mathrm{CH}_{3} \mathrm{OH}_{2}^{+}$ & 567 \\
\hline $\mathrm{CH}_{3} \mathrm{O}$ & 15.5 & & \\
\hline
\end{tabular}

a Value from ref 21; all other values from ref 22. 


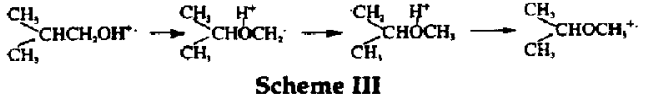

cies of the reactions examined here by determining photoionization efficiency curves [13]. Our results (Table 3) are in reasonable agreement with ones from an earlier study [14], except that our $\mathrm{AE}\left(\mathrm{C}_{3} \mathrm{H}_{7}^{+}\right)$is $27 \mathrm{~kJ}$ $\mathrm{mol}^{-1}$ below that previously reported, and our $\mathrm{AE}\left(\mathrm{C}_{3} \mathrm{H}_{\mathrm{h}}^{+}\right)$is $26 \mathrm{~kJ} \mathrm{~mol}^{-1}$ lower. The onsets of $\mathrm{C}_{3} \mathrm{H}_{7}^{+}$, $\mathrm{C}_{3} \mathrm{H}_{6}^{+}, \mathrm{CH}_{3} \mathrm{OH}_{2}^{+}$, and $\mathrm{CH}_{2}=\mathrm{OH}^{+}$formation from 2-methylpropanol (1) cover an $85 \mathrm{~kJ} \mathrm{~mol}^{-1}$ energy range. However, all are close to corresponding thermochemical thresholds (see Table 3). If Scheme I is correct in assuming that the second and third species are formed through 3 , that complex must form down to at least $59 \mathrm{~kJ} \mathrm{~mol}^{-1}\left(\mathrm{AE}\left[\mathrm{C}_{3} \mathrm{H}_{7}^{+}\right]-\mathrm{AE}\left[\mathrm{CH}_{3} \mathrm{OH}_{2}^{+}\right]\right)$ below the threshold for dissociation of 3 . This indicates much stronger attractions in $\mathbf{3}$ than in ion-nonpolar neutral complexes, as eliminations through the latter usually begin no more than about $20-30 \mathrm{~kJ}$ $\mathrm{mol}^{-1}$ below the threshold for simple dissociation of the initial partners [15].

Eliminations through ion-nonpolar neutral complexes rapidly diminish in importance as the energy in the system rises above the threshold for simple dissociation of the initial partners [15-17]. Significant evidence for this is that PIE curves for eliminations involving $\mathrm{H}$-abstractions by alkyl radical partners level off just above the thresholds for simple dissociation of complexes [15]. Because the threshold law for photoionization is a step function for each product state, the number of ions formed containing the energy
hv-IE is proportional to the slope of the PIE curve [18]. The PIE curves for $\mathrm{C}_{3} \mathrm{H}_{6}^{+}$and $\mathrm{CH}_{3} \mathrm{OH}_{2}^{+}$formed from 1 rise without leveling up to at least 181 and 214 $\mathrm{kJ} \mathrm{\textrm {mol } ^ { - 1 }}$ above their onsets (Figure 2). This demonstrates that $\mathrm{H}$-transfers in 3 and 4 take place well above the thresholds for their simple dissociation. Therefore ion-dipole complexes can be significant intermediates over a much wider energy range than can ion-induced dipole complexes. Recent photoionization efficiency curves for fragmentations through alcohol-containing [3] and alkoxy-containing [4] complexes support this conclusion.

lonized n-butanol (2). Like 1, ionized n-butanol (2) fragments to $\mathrm{C}_{3} \mathrm{H}_{7}^{+}, \mathrm{C}_{3} \mathrm{H}_{6}^{+}, \mathrm{CH}_{3} \mathrm{OH}_{2}^{+}$, and $\mathrm{CH}_{2}=$ $\mathrm{OH}^{+}$, although the abundance of $\mathrm{CH}_{3} \mathrm{OH}_{2}^{+}$is lower and the loss of water dominant (see Table 1). In contrast to formation of 3 from 1, the charge might go to either fragment during complex-forming alpha cleavage of 2 near threshold. Based on the heats of formation of the dissociated partners and estimated binding energies, the complex containing $\mathrm{CH}_{2}=\mathrm{OH}^{+}$ should be the more stable one (Figure 3 ), although either complex is energetically accessible at the threshold for forming $\mathrm{CH}_{3} \mathrm{CH}_{2} \mathrm{CH}_{2}{ }^{+}+\mathrm{CH}_{2}=\mathrm{OH}^{+}$.

Assuming that concerted eliminations do not occur at low energies, the distribution of labels in protonated methanols produced from deuterated forms of 2 (Table 4) demonstrates that $2 \rightarrow 9$ occurs. Although there was $\mathrm{H}$-transfer from all positions in the propyl to both $O$ and $C$ of the protonated methanol daughter, there was a preference for transfer from $\mathrm{C} 3$ to the carbon and from $\mathrm{C} 4$ (numbering as in 2) to the oxy-

Table 3. Photoionization appearance energies for butanols ( $\left.\mathrm{kJ} \mathrm{mol}{ }^{-1}\right)$

\begin{tabular}{|c|c|c|c|c|c|c|}
\hline \multicolumn{4}{|c|}{ 2-Methylpropanol } & \multicolumn{3}{|c|}{ n-Butanol } \\
\hline$m / z$ & Present & Predicted & Ref 14 & Present & Expected & Ref 14 \\
\hline 74 & $971 \pm 3$ & & $967 \pm 5$ & $964 \pm 3$ & & 964 \\
\hline 56 & $1000 \pm 2$ & $916^{a}, 980^{b}$ & $997 \pm 3$ & $981 \pm 2$ & $\begin{array}{l}971^{b}, 1018^{c} \\
957^{d}\end{array}$ & 982 \\
\hline 43 & $1061 \pm 5$ & $1057^{\circ}$ & $1088 \pm 3$ & $1084 \pm 5$ & $1048^{\circ}, 1130^{f}$ & \\
\hline 42 & $1035 \pm 3$ & $1041^{9}, 1086^{h}$ & $1061 \pm 3$ & $1074 \pm 5$ & $1032^{\mathrm{s}}, 1077^{\mathrm{h}}$ & \\
\hline 33 & $1002 \pm 3$ & 1012 & $1006 \pm 3$ & $1069 \pm 5$ & 1003 & \\
\hline 31 & $1087 \pm 3$ & $1080^{i}$ & & $1088 \pm 3$ & $1078^{i}$ & \\
\hline
\end{tabular}

Products associated with the predicted thresholds

${ }^{a} \mathrm{CH}_{3} \mathrm{C}_{\left(\mathrm{CH}_{3}\right)=\mathrm{CH}_{2}^{+}}$

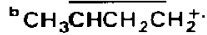

c $\mathrm{CH}_{2} \mathrm{CH}_{2} \mathrm{CH}_{2} \mathrm{CH}_{2}^{+}$.

${ }^{d} \mathrm{CH}_{3} \mathrm{CH}_{2} \mathrm{CH}=\mathrm{CH}_{2}^{+}$

${ }^{\circ} \mathrm{CH}_{3}^{+} \mathrm{CHCH}_{3}$

${ }^{+} \mathrm{CH}_{3} \mathrm{CH}_{2} \mathrm{CH}_{2}^{+}$

${ }^{9} \mathrm{CH}_{3} \mathrm{CH}=\mathrm{CH}_{2}^{+}$

h $\mathrm{CH}_{2} \mathrm{CH}_{2} \mathrm{CH}_{2}^{+}$

${ }^{i} \mathrm{CH}_{3} \cdot \mathrm{CHCH}_{3}$

${ }^{\mathrm{i}} \mathrm{CH}_{3} \mathrm{CH}_{2} \mathrm{CH}_{2}$

$\Delta \mathrm{H}_{\text {cor }}$ a statistical mechanical correction factor for the thermal energy content of the fragments [13], is typically $18 \mathrm{~kJ} \mathrm{~mol} 1$ for these decompositions. Thus, all predicted AEs should be lowered by about that amount. 

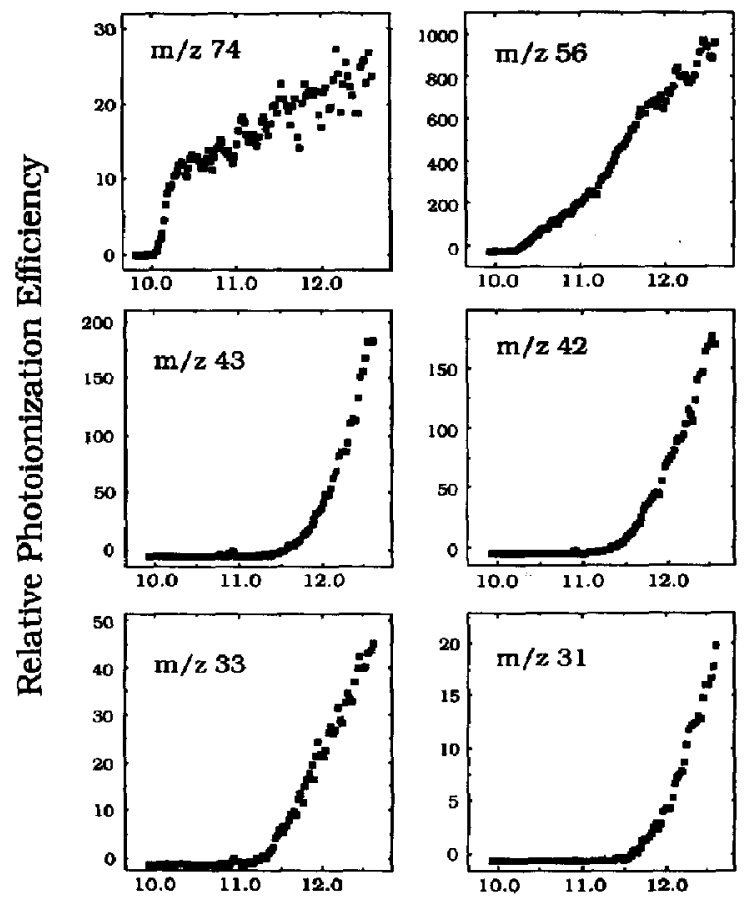

Photon Energy /eV

Figure 2. Photoionization efficiency curves for the formation of $\mathrm{C}_{4} \mathrm{H}_{8}^{+} ; \mathrm{C}_{3} \mathrm{H}_{7}^{+}, \mathrm{C}_{3} \mathrm{H}_{6}^{+}, \mathrm{CH}_{3} \mathrm{OH}_{2}^{+}$, and $\mathrm{CH}_{2} \mathrm{OH}^{+}$from ionized 2-methylpropanol. Note that only the $\mathrm{C}_{4} \mathrm{H}_{8}^{+-}$curve levels off with increasing photon energy, indicating that each of the other processes is important up to the energy at the upper limit of the measurements.

gen. By analogy to arguments given above for complex-mediated elimination of methanol and formation of protonated methanol from 1, formation of protonated methanol is attributed to $2 \rightarrow 9 \rightarrow 4 \rightarrow \mathrm{CH}_{3} \mathrm{OH}_{2}^{+}$. The specificity of the initial H-transfers could be substantially obscured by exchange by $4 \neq 5$ and $4 \rightleftarrows 3$, as happens in the dissociations of 1 [6]. This (Scheme IV) or isomerization of $n-\mathrm{C}_{3} \mathrm{H}_{7}^{+}$in a complex (Scheme V) may precede reactions such as $\mathrm{H}$ transfer from $\mathrm{C2}$ and $\mathrm{C} 4$ (numbering as in 2) of the propyl to $\mathrm{C}$ in the generation of $\mathrm{CH}_{3} \mathrm{OH}_{2}^{+}$.

$i-\mathrm{C}_{3} \mathrm{H}_{7}^{+}$is formed from 2, as $\mathrm{AE}\left(\mathrm{C}_{3} \mathrm{H}_{7}^{+}\right)$is $46 \mathrm{~kJ}$ mol $^{-1}$ below the predicted $\mathrm{AE}\left(\mathrm{CH}_{3} \mathrm{CH}_{2} \mathrm{CH}_{2}^{+}\right.$) (see Table 3). $i-\mathrm{C}_{3} \mathrm{H}_{7}^{+}$and $\mathrm{CH}_{3} \mathrm{OH}_{2}^{+}$could be formed through $\left[\mathrm{CH}_{3} \mathrm{CH}_{2} \mathrm{CH}_{2} \cdot \mathrm{CH}_{2} \mathrm{OH}^{+}\right]$, as shown in Scheme IV. $i-\mathrm{C}_{3} \mathrm{H}_{7}^{+}$could also form through 10 (see Scheme V), as primary alkyl ions usually isomerize before dissociation of complexes [19] because such ions do not exist in potential minima.

$\mathrm{AE}\left(\mathrm{C}_{3} \mathrm{H}_{6}^{+}\right)$and $\mathrm{AE}\left(\mathrm{CH}_{3} \mathrm{OH}_{2}^{+}\right)$are within experimental uncertainty of each other and about $16 \mathrm{~kJ}$ mol $^{-1}$ below $\mathrm{AE}\left(\mathrm{CH}_{2}=\mathrm{OH}^{+}\right)$. This meets expectations for decomposition of 2 through $\left[\mathrm{CH}_{3} \mathrm{CH}_{2} \mathrm{CH}_{2}\right.$. $\left.\mathrm{CH}_{2}=\mathrm{OH}^{+}\right]$because the thresholds for ion-nonpolar neutral complex-mediated processes are usually no more than $20-30 \mathrm{~kJ} \mathrm{~mol}^{-1}$ below the threshold for simple dissociation of the complex [15]. The narrow range of the onsets of the decompositions of 2 contrasts with the larger differences between the onsets for the corresponding decompositions of 1 . The onsets for $\mathrm{C}_{3} \mathrm{H}_{6}^{+}, \mathrm{CH}_{3} \mathrm{OH}_{2}^{+}$, and $\mathrm{C}_{3} \mathrm{H}_{7}^{+}$formation from 2 are, respectively 42,66 , and $36 \mathrm{~kJ} \mathrm{~mol}^{-1}$ above their thermochemical thresholds (see Table 3). Onsets of complex-mediated dissociations can be significantly above the product heats of formation when the latter are more stable than the products of simple dissociation of the partners in the complex [15d]. "Conventional" mechanisms (e.g., Scheme III) would predict similar threshold behavior for the corresponding products from 1 and 2; the contrasts observed are added evidence for the occurrence of the proposed complex-mediated processes.

The PIE curve for $\mathrm{CH}_{3} \mathrm{OH}_{2}^{+}$formation from 2 rises continuously for at least $145 \mathrm{~kJ} \mathrm{~mol}^{-1}$ above onset without signs of leveling, in contrast to expectations for formation of $\mathrm{CH}_{3} \mathrm{OH}_{2}^{+}$through an ion-nonpolar neutral romplex such as 9. This suggests that $\left[\mathrm{CH}_{3} \mathrm{CH}_{2} \mathrm{CH}_{2}^{+} \cdot \mathrm{CH}_{2} \mathrm{OH}\right]$ becomes important at higher energies (see Scheme $\mathrm{V}$ ). The polarity of the neutral partner in this complex would expand the energy range upward, as in the decompositions of 1 .

One of our objectives was to determine why much more $\mathrm{CH}_{3} \mathrm{OH}_{2}^{+}$is formed from 1 than from 2. One reason for this is that, relative to $2, \mathrm{CH}_{3} \mathrm{OH}_{2}^{+}$is generated from 1 starting much further below the onset of simple dissociation of the partners in the complex. Thus more $\mathrm{CH}_{3} \mathrm{OH}_{2}^{+}$is formed from 1 than from 2 because $\mathrm{CH}_{3} \mathrm{OH}_{2}^{+}$is formed from 1 over a wider energy range. This is attributable to differences between the energy dependencies of reactions in ioninduced dipole complexes and ion-dipole complexes.

Water elimination: competition of a lower energy conventional isomerization with complex-mediated elimination. The threshold for $\mathrm{H}_{2} \mathrm{O}$ elimination from 1 is $2 \mathrm{~kJ}$ mol ${ }^{-1}$ below that for $\mathrm{CH}_{3} \mathrm{OH}_{2}^{+}$formation (see Table 3 ). This small difference causes loss of water to be the major and $\mathrm{CH}_{3} \mathrm{OH}_{2}^{+}$the minor metastable decomposition of 1 [9]. The $\mathrm{C}_{4} \mathrm{H}_{8}^{+}$. threshold is just above that for forming ionized methylcyclopropane, the main product of water elimination from 1 [8]. The slope of the PIE curve for this process becomes close to zero less than $20 \mathrm{~kJ} \mathrm{~mol}^{-1}$ above threshold. Therefore, $1 \rightarrow 6$ is confined to very low energies [18]. This and the difference in $\mathrm{H}$-exchange accompanying the two fragmentation pathways (see above) suggest that $1 \rightarrow 6$ occurs largely below the threshold for complex formation $1 \rightarrow 3$. Loss of water is also the lowest energy decomposition of 2 , in this instance by about $90 \mathrm{~kJ}$ $\mathrm{mol}^{-1}$. The methylcyclopropane ion is also a major product of water elimination from 2, even following $2 \rightarrow{ }^{\circ} \mathrm{CH}_{2} \mathrm{CH}_{2} \mathrm{CH}_{2} \mathrm{CH}_{2} \mathrm{OH}_{2}^{+}$, whereas the cyclobutane ion is not detectable [8]. $\mathrm{AE}\left(\mathrm{C}_{4} \mathrm{H}_{8}^{+} \cdot\right)$ is that expected 


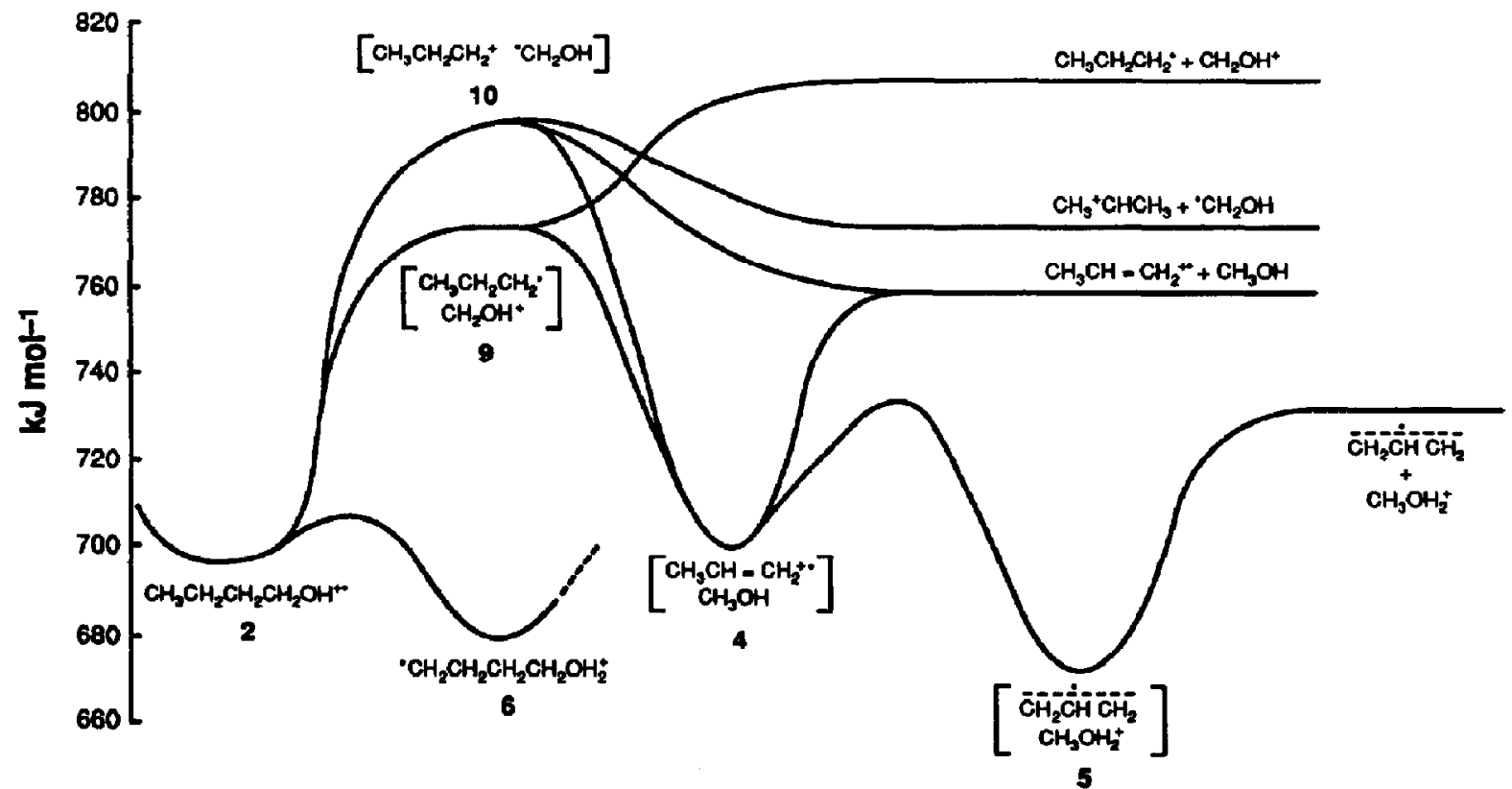

Figure 3. Potential energy diagram for the dissociations of ionized $n$-butanol (2). The dissociated species and 2 are placed according to the values in Table 1.6 is placed $17 \mathrm{~kJ} \mathrm{~mol}^{-1}$ below 2 based on $\Delta \mathrm{H}_{\mathrm{f}}\left(\mathrm{CH}_{3} \mathrm{CH}_{2} \mathrm{CH}_{2} \mathrm{OH}^{+\cdot}\right)-\Delta \mathrm{H}_{\mathrm{f}}\left(\mathrm{CH}_{2} \mathrm{CH}_{2} \mathrm{CH}_{2} \mathrm{OH}_{2}^{+}\right)$[22]. Attractions of 59 and $30 \mathrm{~kJ} \mathrm{~mol}$ were assumed between charged and polar and nonpolar neutral partners, respectively. (See legend to Figure 1.)

for the methylcyclopropane ion (see Table 3). The formation of $\mathrm{CH}_{3} \mathrm{OH}_{2}^{+}$from 2 demonstrates that some complex formation competes with the H-transfer that leads to water loss and that complex-mediated processes can compete with substantially lower energy hydrogen transfers. This contrasts with a conclusion [17] that ion-nonpolar neutral complex-mediated reactions are generally not competitive with lower threshold processes. The ability to compete with other types of reactions well above the threshold for simple dissociation of the partners is thus another difference between the reactions of complexes containing polar versus those containing nonpolar neutral partners.

\section{Summary}

Several significant conclusions emerge from the present study. First, complex-mediated reactions occur over wide energy ranges when the neutral partner is polar, in contrast to the very narrow energy range of such reactions when the neutral partner is small and nonpolar [15-17]. Second, ion-polar neutral complexmediated reactions can compete with lower energy isomerizations. Finally, H-exchange between partners in an ion-neutral complex can be very fast.

\section{Experimental}

Photoionization efficiency curves were determined with a microprocessor-controlled photoionization magnetic sector mass spectrometer, as described elsewhere [13]. AE values were obtained by linear extrapolation of the initial rising portion of the curve to the abscissa. Corrections for influences of thermal energy on the curves were made by comparisons to the PIE

Table 4. Protonated methanol formation from labeled $n$-butanol ions $\boldsymbol{s}^{\mathrm{a}}$

\begin{tabular}{lccccc}
\hline & $\mathrm{CH}_{3} \mathrm{OH}_{2}^{+}$ & $\mathrm{CH}_{3} \mathrm{OHD}^{+}$ & $\mathrm{CH}_{2} \mathrm{DOH}_{2}^{+}$ & $\mathrm{CH}_{2} \mathrm{DOHD}^{+}$ & $\mathrm{CH}_{3} \mathrm{OD}_{2}^{+}$ \\
\hline \hline $2-2,2-\mathrm{d}_{2}$ & 62 & 21 & 17 & & \\
$2-3,3-\mathrm{d}_{2}$ & 44 & 19 & 34 & 3 & $3^{\mathrm{b}}$ \\
$2-4,4,4-\mathrm{d}_{3}$ & 19 & 55 & 17 & 4 & 5 \\
\hline
\end{tabular}

\footnotetext{
a Abundances determined from the peak heights in the normal mass spectrum of each species and the areas of the peaks representing $\mathrm{C}(\mathrm{H}, \mathrm{D})_{3}^{+}$products of the collision-induced dissociation of protonated methanal.

${ }^{6}$ Composite intensities of $\mathrm{CH}_{2} \mathrm{DOHD}{ }^{+}$and $\mathrm{CH}_{3} \mathrm{OD}_{2}^{+}$.
} 

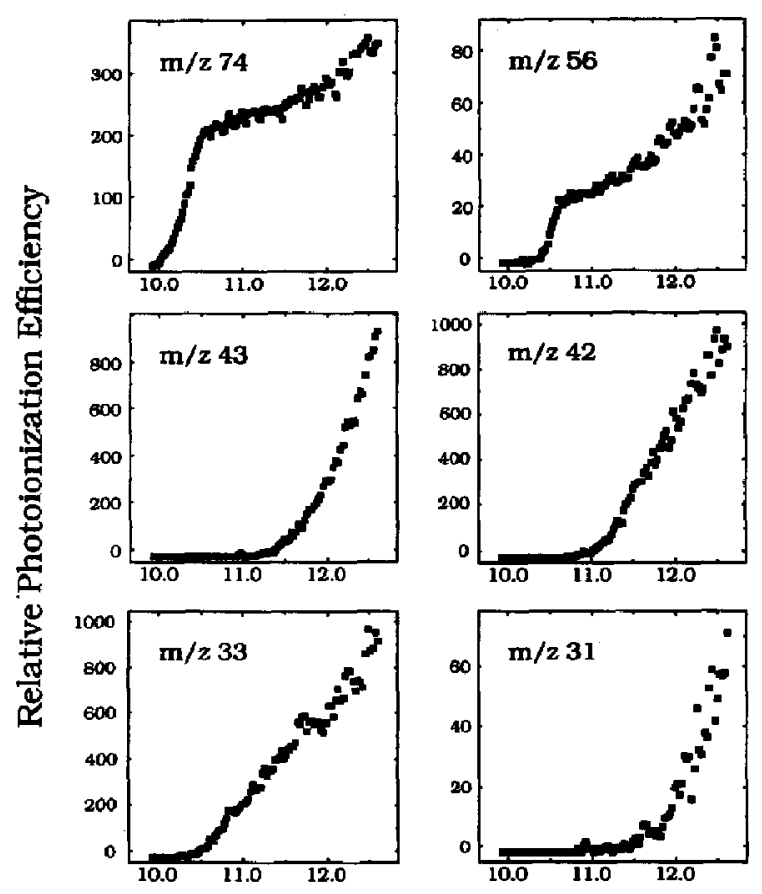

\section{Photon Energy /eV}

Figure 4. Photoionization efficiency curves for the formation of $\mathrm{C}_{4} \mathrm{H}_{3}^{+} ; \mathrm{C}_{3} \mathrm{H}_{7}^{+}, \mathrm{C}_{3} \mathrm{H}_{6}^{+} ; \mathrm{CH}_{3} \mathrm{OH}_{2}^{+}$, and $\mathrm{CH}_{2} \mathrm{OH}^{+}$from ionized $n$-butanol. Note that none of the curves level off with increasing photon energy. Therefore, each of these processes is important up to the upper limit of the measurements.

curves for the corresponding molecular ions. The AE measurements are reproducible to $\pm 1 \mathrm{~kJ} \mathrm{~mol}^{-1}$, but the uncertainties due to the contribution of thermal energy can be larger.

Collision-induced dissociation was achieved by pressurizing with helium the collision cell between the magnetic sector and second electric sector of a mass spectrometer of the geometry electric sectormagnetic sector-electric sector [20]. The ions that were collided were produced by ionization with $70 \mathrm{eV}$ electrons in the ion source of the mass spectrometer. Spectra were recorded by scanning the voltage on the second electric sector following sample admissinn and pressurization of the collision cell.

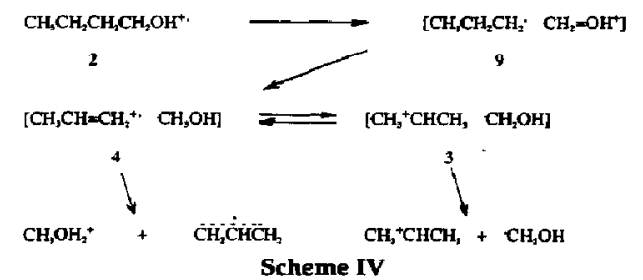

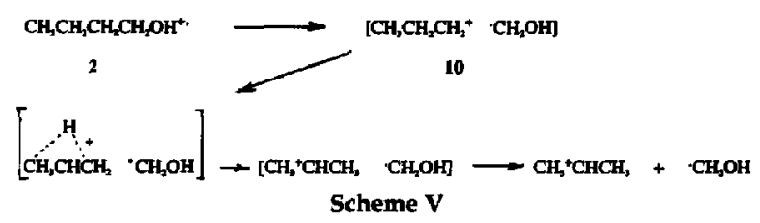

\section{Acknowledgments}

We thank the Robert A. Welch Foundation (H-609), the Petroleum Research Fund, and the Australian Research Grants Scheme for financial support. Professor Michael Gross and the National Science Foundation-supported Midwest Center for Mass Spectrometry for use of the Kratos MS 50TA mass spectrometer, and Ms. Debbie Pavlu for typing.

\section{References}

1. (a) Morton, T. M. Tetrahedron 1982, 38, 3195-3243. (b) McAdoo, D. J. Mass Spectrom. Reo. 1988, 7, 363-393.

2. Su, T.; Bowers, M. T. In Gas Phase Ion Chemistry, Vol. I; Bowers, M. T., Ed.; Academic: New York, 1979; p 83.

3. Ahmed, M. S.; Hudson, C. E.; Traeger, J. C.; Giam, C. S.; McAdoo, D. J. I. Am. Chem. Soc. 1990, 112, 6443-6445.

4. Traeger, J. C.; Hudson, C. E.; McAdoo, D. J. J. Am. Soc. Mass Spectrom., 13(2), (in press).

5. (a) Bowen, R. D.; Williams, D. H. J. Chem. Soc. Chem. Comm. 1981, 836-838. (b) Bowen, R. D. J. Chem. Soc. Perkin Trans. II. 1984, 1005-1007. (c) Bissonnette, M. C.; George, M.; Holmes, J. L. Org. Mass Spectrom. 1990, 25, 689-693.

6. Tajima, S.; van der Greef, J.; Nibbering, N. M. M. Org. Mass Spectrom. 1978, 13, 551-555.

7. McAdoo, D. J.; Ahmed, M. S.; Hudson, C. E.; Giam, C. S. Int. J. Mass Spectrom. Ion Processes 1990, 100, 579-593.

8. Ahmed, M. S.; Hudson, C. E.; Giam, C. S.; McAdoo, D. J. Org. Mass Spectrom., 1991 26, 1089-1091.

9. McAdoo, D. J.; Hudson, C. E. Org. Mass Spectrom. 1987, 22, 615-621.

10. Hammerum, S.; Derrick, P. J. J. Chem. Soc. Perkin Trans. II. 1986, 1577-1580.

11. Weber, R.; Levsen, K.; Wesdemiotis, C.; Weiske, T.; Schwarz, H. Int. J. Mass Spectrom. Ion Phys. 1982, 43. 131-155.

12. Leger, L.J.; Meisels, G. G.; Tiernan, T. O. I. Chem. Phys. $1970,52,4319-4324$.

13. (a) Traeger, J. C.; McLoughlin, R. G. Int. J. Mass. Spectrom. Ion Phys. 1978, 27, 319-333. (b) Traeger. J. C.; McLoughlin. R. G. J. Am. Chem. Soc. 1981, 103, 3647-3652. (c) Traeger, J. C.; McLoughlin, R. G.; Nicholson, A. J. C. J. Am. Chem. Soc. 1982, 104, 5318-5322.

14. Shao, J. D.; Baer, T.; Lewis, D. K. I. Phys. Chem. 1988, 92, 5123-5128.

15. (a) Traeger, J. C.; Hudson, C. E.; McAdoo, D. J. J. Phys. Chem. 1988, 92, 1519-1523. (b) McAdoo, D. J.; Traeger, J. C.; Hudson, C. E.; Griffin, L. L. I. Phys. Chem. 1988, 92, 1524-1530. (c) Traeger, J. C.; Hudson, C. E.; McAdoo, D. J. J. Phys. Chem. 1990, 94, 5714-5717. (d) McAdoo, D. J.; Traeger, J. C.; Hudson, C. E.; Grose, A.; Griffun, L. J. Am. Soc. Mass Spectrom. 1991, 2, 261-269.

16. Heinrich, N.; Louage, F.; Lifshitz, C,; Schwarz, H. J. Am. Chem. Soc, 1988, 110, 8183-8192.

17. Hudson, C. E.; McAdoo, D. J. Int. I. Mass Spectrom. Ion Processes 1984, 59, 325-332.

18. Hurzeler, H.; Inghram, M. G.; Morrison, J. D. J. Chem. Phys. 1958, 28, 76-82.

19. (a) Williams, D. H.; Stapleton, B. J.; Bowen, R. D. Tetrahe- 
dron Letters 1978, 2919-2992, (b) Bowen, R. D.; Stapleton, B. J.; Williams, D. H. T. Chem. Soc. Chem. Commun. 1978, 24-26. (c) Bowen, R. D.; Williams, D. II. Int. I. Mass Spectrom. Ion Phys. 1979, 29, 47-55. (d) Wendelboe, J. F.; Bowen, R. D.; Williams, D. H. J. Am. Chem. Soc. 1981, 103 , 2333-2339.

20. Gross, M. L.; Chess, E. K.; Lyon, P. A.; Crow, F. W.;
Evans, S.; Tudge, H. Int. J. Mass Spectrom. Ion Phys. 1982, $42,243-254$.

21. Traeger, I. C. Int. J. Mass Spectrom. Ion Processes 1984, 58, $259-271$.

22. Lias, S. G.; Bartmess, J. E.; Liebman, J. F.; Holmes, J. L.; Levin, R. D.; Mallard, W. G. J. Phys, Chem. Ref. Data 1988, 17, Suppl. 1. 